Saeculum Christianum

vol. XXII (2015)

pp. $69-79$

\author{
PATRYCJA EWA HEROD * \\ WNHiS UKSW, Warszawa
}

\title{
THE REGULATIONS IN THE FIELD OF CRIMINAL LAW IN THE STATUTE OF SOCHACZEW OF 27 APRIL 1377
}

\begin{abstract}
Acz myedzy nyekthorimy ludzmy kthorego kolibi stadla bily valka albo zwada przygodzylabi syan thedi on komu oczyecz brath abo ktho s prziyaczol przes nyekogo bilbi zabith, schvkacz crzywego i patrzacz ma, ale sprawyedliwego nyema gabacz paklibi smyalosczyąn zlosczywąn prawego $w$ domu albo procza domu nagabal tedi ten czo nagaba czczy i gymyenya ma bycz zbawyon, a ossobnye se schiyan varowacz syąn musi.

O manzoboysthwye, para 7 of the Statute of 27 April 1377, issued in Sochaczew by Siemowit III, translated Maciej of Różan ${ }^{1}$.
\end{abstract}

After the death of Duke Bolesław II of Masovia ${ }^{2}$ in 1313, the next and the same time the last sovereign ruler of the entire Masovia was only Siemowit $\mathrm{III}^{3}$, who ruled over all the lands of Masovia from 1370 to the turn of 1373/74, when he determined the borders for his

\footnotetext{
* Translated by Spektra Sp. z o.o.

Prawa ksiąząt mazowieckich / transl. into Polish by Maciej of Różan, 1450, homography reprint from the Kórnik Code made by. A. Piliński, Kórnik 1877, p. 2 (according to the pagination adopted by the author of the article, due to the failure of Maciej of Różana to introduce numbers); cf. J. Lelewel, Księgi ustaw polskich i mazowieckich, Wilno 1824, p. 134; See: Iura Masoviae Terrestria: pomniki dawnego prawa mazowieckiego ziemskiego (dalej: IMT), ed. J. Sawicki, vol. 1 (1228-1471), Warszawa 1972, No.22, art. 7: Actor homicidii queratur, p. 30.

2 Bolesław II (ca. 1253/58-1313), the son of Siemowit I, brother of Konrad II, a co-regent (with his brother) until 1275, when as a result of the partition of Masovia he became the Duke of Płock, in the years 1288-89 in Sandomierz, the ruler over the entire Masovia from 1294. [O. Balzer, Genealogia Piastów, Kraków 1895, pp. 421-423; J. Grabowski, Dynastia Piastów mazowieckich. Studia nad dziejami politycznymi Mazowsza, intytulacja i genealogia książat, Kraków 2012, p. 272-275, K. Jasiński, Rodowód Piastów mazowieckich, Poznań-Wrocław 1998, pp. 16-23; See: B. Horodyński, Bolesław ii (zm. 1313), Polski Słownik Biograficzny (hereinafter: PSB), vol. 1-7, Kraków 1935-58; vol. 8-15, Wrocław-Warszawa-Kraków 1959-70; vol. 16-25, Wrocław-Warszawa-KrakówGdańsk 1971-1980; vol. 26-31, Wrocław-Warszawa-Kraków-Gdańsk-Łódź 1981-88; vol. 32-34, WrocławWarszawa-Kraków 1989-93; vol. 35-50, Warszawa-Kraków 1994-2015, vol. 2, p. 267].

3 Siemowit III (1316/25-1381), the son of Trojden I, the brother of Bolesław George II and Casimir I, a co-regent (with his brother Casimir I) of the lands of Warsaw in Czersk from 1341, from 1345 of Rawa, from ca. 1349, as a result of the partition, he became the Duke of Czersk, Liw and Rawa, from 1351 the ruler of Gostynin, from 1351 the vassal of Poland, from 1352 the Duke of Płock, from 1355 in Warsaw and Sochaczew, from 1370 a sovereign ruler, also in Płock, from 1370 in Zakroczym and Wizno. [O. Balzer, Genealogia, op. cit., pp. 457-458; J. Grabowski, Dynastia, op. cit., pp. 288-297, 443-444; K. Jasiński, Rodowód Piastów mazowieckich, op. cit., pp. 61-68; See: K. Jasiński, Siemowit III (ca. 1320-1381), PSB, vol. 37, pp. 73-75].
} 
sons, Siemowit $\mathrm{IV}^{4}$ and Janusz I the Elder ${ }^{5}$. The renewed independence of the region of Masovia was the consequence of the death of King Casimir III the Great, who died on 5 November 1370, leaving no legal descendants in the male line. Following the agreements of 27 December 1355, it was a mandatory condition for the expiry of the dependence of the Fiefdom of Masovia from the Kingdom of Poland, because the homage of Duke Siemowit III was limited only to the person of the king and his potential male descendants ${ }^{6}$. The Duke of Masovia (dux Masoviae) could also boast of significant achievements in the internal policy. The implementation of new administrative partition around the middle of the 15th century constituted a prelude to a major administrative and judicial reform, which shaped three official hierarchies concerning: court, land, administration, and became the foundation of the ziemia (territorial) judiciary system. After such momentous reforms and the consolidation of all the Masovian lands under one crown, it was obvious that the customary law of Masovia should be unified, written and promulgated.

Customary law, being a set of unwritten legal norms resulting from various types of behaviour practised by members of a given group with the approval of the majority and in public, constituted the basic source of law in Masovia almost until the end of the 14th century. The customary nature of the law did not prejudge its invariance, as the court practice adjusted custom to changing circumstances and needs. Until the independent, Masovian state ceased to exist, the custom was repeatedly referred to in public and private diplomas as well as in statutes as the source of their validity, implied by the conclusion that customary law invariably enjoyed great authority among indigenous people. The manifestation of the desire to unify customs and adapt them to new social conditions was clearly visible in the statutory activity of the Masovian dukes. The Statutes (statuta, articuli terrestres) were written laws regulating all areas of both material and procedural law, while the statutes of Masovia eminently respected the regulations on judicial proceedings (processus iudiciarius).

The oldest Masovian statute was issued on 27 April 1377 in Sochaczew by the Duke Siemowit III, with the involvement of his sons, Janusz I the Elder and Siemowit IV, as well as the most prominent dignitaries in the country. The original of the indicated act has not survived however, the text is known from the four manuscript copies two of which are currently lost ${ }^{7}$. The act in question was also published in print, together with other statutes, by: Jan Wincenty Bandtki in Ius Polonicum ${ }^{8}$, Antoni Helcel in Starodawne prawa

\footnotetext{
4 Siemowit IV (ca. 1353/56-1425/26), the son of Siemowit III, the brother of Janusz I and Henryk Mazowiecki, as a result of partition from 1381 the duke of Rawa, Płock, Sochaczew, Gostynin, Płońsk and Wizno, from 1386 a hereditary vassal of Poland, from 1388 of Bełz. [O. Balzer, Genealogia, op. cit., pp. 473-475; J. Grabowski, Dynastia, op. cit., pp. 298-318, 450-451; K. Jasiński, Rodowód Piastów mazowieckich, op. cit., pp. 87-91; See: A. Supruniuk, Siemowit IV (ca 1352-1426), PSB, vol. 37, pp. 76-81].

5 Janusz I the Elder (ca. 1346-1429), the son of Siemowit III, the brother of Siemowit IV and Henryk Mazowiecki, as a result of partition from 1381 the duke of Warsaw, Nur, Łomża, Liw, Ciechanów, Wyszogród and Zakroczym, from 1386 a hereditary vassal of Poland, from 1391 on Podlasie. [O. Balzer, Genealogia, op. cit., pp. 465-467; J. Grabowski, Dynastia, op. cit., pp. 345-354, 444-450; K. Jasiński, Rodowód Piastów mazowieckich, op. cit., pp. 78-83; See: B. Sobol, Janusz i Starszy (ok. 1329-1429), PSB, vol. 10, pp. 581-582].

${ }^{6}$ Nowy kodeks dyplomatyczny Mazowsza (hereinafter: NKDM), ed. J. Sułkowska-Kuraś, S. Kuraś, part 2: Dokumenty z lat 1248-1355, Wrocław 1989; part 3: Dokumenty z lat 1356-1381, ed. J. Sułkowska-Kuraś, S. Kuraś, Wrocław 2000, part 2, No. 338-340.

7 Kod. Bibl. Petersb. Lat. Q II 274,f. 17-18v (lost); Kod. Bibl. Kórnickiej tzw. Dziatyńskich V (D V) (lost); AGAD, MK vol. 1 f. 1-4; AGAD, Arch. Publ. Potockich, rkp. $n r$ 4. [IMT, vol. 1, pp. 28].

8 Ius Polonicum (hereinafter: IP), ed. J. Bandtki, Warszawa 1831, pp. 417-420.
} 
polskiego pomniki ${ }^{9}$ and Jakub Sawicki in Iura Masoviae Terrestria: pomniki dawnego prawa mazowieckiego ziemskiego ${ }^{10}$.

At the same time, the translation of the statute into the Old Polish Language,done before 1450, 'at the order' of the duke Boleslaw IV of Warsaw ${ }^{11}$ by the priest Maciej of Różan ${ }^{12}$. The text has been preserved in a parchment manuscript called the Pulawy Code (Kodeks Puławski), in which he opens the first collection of Masovian statutes from the years 1377$-1426^{13}$. The monument in question was published by Joachim Lelewel in 1824 in its entirety, with the preservation of the original spelling ${ }^{14}$. Moreover, its homographic reprint, made by Adam Piliński, was announced in print thanks to the efforts of the Kórnik Library in 1877. In the absence of source data it is impossible to establish whether Maciej of Różan, while working on the translation of the statutes, made any changes in them in comparison with the original under translation, which did not have to be identical with the original text ${ }^{15}$.

The Statute of Sochaczew of 27 April 1377 shows differences in the content of particular articles as well as in their number and layout, but it should be noted that no edition omitted the introduction. In the edition of Bandtki and Sawicki, the aforemetioned act is divided into 17 articles, whereas in Helcel into 18, while the edition of Sawicki is the basic Latin edition used in the presented considerations ${ }^{16}$. However, in the translation of Maciej of Różan, the indicated act contained as many as 20 articles, two of which were not included in any Latin edition, i.e. Gwalt kmyotownye (XVII) and Manzoboystwo kmyecza (XVIII. Due to the fact that they contain regulations on criminal law, they are very important in the context of the discussed subject matter.

The first penal regulation in the statute announced by Siemowit III in1377 is the fourth paragraph, included in the same place in each edition. Sawicki called it Praescripcio

\footnotetext{
9 Starodawne prawa polskiego pomniki poprzedzone historyczno-krytycznym tak zwanego prawodawstwa wiślickiego Kazimierza wielkiego w texcie ze starych rękopism krytycznie dobranym (hereinafter: H), ed. A. Helcel, vol. 1, Warszawa 1856, pp. 269-274

10 IMT, vol. 1, No. 22, pp. 28-33.

11 Bolesław IV of Warsaw (1418/20-1454), the grandson of Janusz I, from 1429 Duke of Ciechanów, Czersk, Liw, Łomża, Nur, Różan, Warsaw, Wyszogród and Zakroczym (from 1436 independent reign, previously the regency of mother, Anna Fiodorówna), in the years 1440-44 the Duke of Podlasie. [O. Balzer, Genealogia, op. cit., pp. 521-522; J. Grabowski, Dynastia, op. cit., p. 356, 477-478; K. Jasiński, Rodowód Piastów mazowieckich, op. cit., pp. 157-160; See: K. Maleczyński, Bolestaw IV (1421-1454), PSB, vol. 2, pp. 280-281].

12 Maciej of Różan, called Maciej Różański (ca. 1420-1467), Chancellor of Masovia, Treasury writer, canon of Płock and Warsaw, parish priest of Czersk and Maków. [See: I. Sułkowska Kurasiowa, A. Wolff, Maciej z Różana (ca. 1420-1467), kanclerz księcia mazowieckiego Bolesława IV, PSB, vol. 19, pp. 35-36]; S. Kutrzeba, Historia źródet dawnego prawa polskiego, vol. 2, Lwów-Warszawa-Kraków 1926, p. 11.

13 In addition, the collection includes a translation of the Polish statutes by Świętosław of Wojcieszyn. [O. Balzer, Stowo o przekładach polskich statutów średniowiecznych zwłaszcza o kodeksie dzikowskim przekład taki zawierającym, Lwów 1888, pp. 6-7].

14 J. Lelewel, Księgi, op. cit., pp. 133-152.

15 S. Russocki, Z badań nad statutami książąt mazowieckich z XIV i XV wieku, „Czasopismo Prawno-Historyczne” No. 8/1956, z. 2, p. 246.

16 The disparities concerning the above editions shall be presented on an ongoing basis in the footnotes.
} 
maleficiorum $^{17}$, whereas Maciej of Różan $O$ vivolanych zloczinczach ${ }^{18}$. The aforementioned provision obliged the Dukes Siemowit III, Janusz I the Elder and Siemowit IV to prepare a list of all criminals, regardless of their state affiliation, who committed the so-called villainy in their domains, i.e. mugging or thievery ${ }^{19}$, and to communicate the arrangements to one another in writing. At the same time, the paragraph in question maintained that the persons included in the lists were to be called up and that until they proved their innocence and were cleared they would face a penalty commensurate with the crime they had committed.

Professionally practised robberies and thefts were classified as the most serious crimes and were prosecuted ex officio. Mugging (latrociniam) related to outrage acts committed for the purpose of robbery and in case of a call-up, all citizens and officials were obliged, not only to prosecute and catch the robbers, but also to bring them to competent local authorities ${ }^{20}$. The Masovian sources, which have survived to this day, do not specify the penalty to be imposed on a criminal for mugging but since the thief was punishable by the death penalty and both crimes were classified into one category, it is highly probable that the Masovian law provided for the same penalty for mugging. However, the penalty of proscription, in other words calling up, was announced in public after the decision had been rendered in absentia. The call-up resulted in the so-called civil death (fictitious death) of the proscribed person, who ceased to exist for the law as a person, and thus was deprived of legal status and the capacity to perform legal acts, and whose property was confiscated. In addition, he was forbidden to stay within the borders of the $s t^{21}$. The wife of the called person became a widow by law and could enter a new marital union, while the children were considered orphans ${ }^{22}$.

Apart from the above, it should be pointed out that the preparation of three lists by each Duke separately was motivated by the then division of Masovian lands into three rulerships, made by Siemowit III between 12 May 1373 and 5 January 1374. Then Janusz I the Elder received the lands of: Ciechanów, Wisk, Warszawa and Zakroczym, Siemowit IV the lands of Czersk with Liw and Rawa and their father kept the lands of north-western Masovia with Gostynin, Płock, Płońsk, Sochaczew and Wyszogród ${ }^{23}$.

17 „Item domini duces Semovitus senior, iohannes et Semovitus iuniores, omnes suos malefactores seu fures vel latrones, cuiuscunque condicionis fuerint aut status conscribere [debent mandere] et eosdem unus ad alterum in scriptis enarrare. Et si quis ex eisdem prescriptis suam innocenciam et infamiam non curaverit expurgare, extunc iuxta factum suum, prout demeruit, licite sustinere debet". [IMT, vol. 1, pp. 29-30]; There is no numbering in Bandki, except the headlines, but the fourth paragraph has the following title Consriptio malefactorum [IP, p. 418]; Helcel introduced the Roman numbering in the Latin text without taking into account the titles and he placed its translation into Polish next to each paragraph, contenting himself with giving the headlines also in Polish, and Article IV in his edition is identical with the paragraph 4: Praescripcio maleficiorum in Sawicki [H, p. 270$].$

18 „Item. Xąnzantha Semouith stari Jan i Semouith mlothschi wschithky swe zloczincze albo zlodzyeye lotri ktorego kolibi stadla albo powysschenya bili mayąn popissacz a yeden od drvego napysmyenyv wszkazacz paklibi ktho tich violannich swey nyewinnosczy $i$ ganybi nyedbal oczisczicz tedi podlug vczinkv swego yako zasluzil dostoynie czyrzpyecz bąndzye”. [Prawa, op. cit., p. 2; cf. J. Lelewel, Księgi, op. cit., p. 134].

19 In the Masovian law, a distinction should be made between a single theft and thievery, understood as persistent professional theft.

20 See: land privilege of 18 IX 1447 for the nobility of the following poviats: Nowogród, Lomża, Liw, Nur, Maków, Różan, Ostrów and Ostrołęka [IMT, vol. 1, No. 94; cf. Kodeks dyplomatyczny Księstwa Mazowieckiego, obejmujący bulle papieżów, przywileje królów polskich i książą mazowieckich, tudzież nadania tak korporacyj jako i osób prywatnych, ed. J. Lubomirski, Warszawa 1863, No. 194].

${ }^{21}$ J. Bardach, B. Leśnodorski, M. Pietrzak, Historia ustroju i prawa polskiego, Warszawa 2003, p. 160.

22 J. Rafacz, Dawne polskie prawo prywatne, Warszawa 1925, pp. 22, 131.

23 NKDM, part 3, No. 136. 
A clear proof showing that thievery was committed repeatedly in Masovia in the second half of the 14th century and that it constituted a major social problem, is the fact that four articles in the statute of 1377 were devoted to the indicated issue. Paragraph 8, entitled De inculpato pro forticinio ${ }^{24}$ in Iura Masoviae Terrestria, and in the translation of Maciej of Różan, given as article 9 and bearing the headline Gdi kogo obvynyąn o zlodzyestwo ${ }^{25}$, regulated the way of exoneration of theft (furtum, furticinium), which looked the same both in the case of a previous accusation and the very suspicion of its perpetration, which was treated as a grave insult. In order to acquit oneself of the charge of thievery, the accused person was obliged to bring 6 relatives of three bloodlines to the court, i.e. two of each parent (on the father's and mother's side) and two on the side of the father's mother, both settled and well known, who, as witnesses, were to take an oath purifying him of the accusations against him, but he himself could not take the oath on his own behalf.

The next regulation regarding the aforementioned criminal offence was article 11, Inculpatus pro furticinio per principem ${ }^{26}$, which in the translation of Różański was entitled Gdy xanzan obvyni kogo o zlodzyestwo ${ }^{27}$ and was mentioned as 12 . Under the indicated provision, a thief who was indicted by the Duke and failed to exonerate himself within 18 weeks was subject to the death penalty and a confiscation of both movable and immovable property for the benefit of the ruler. Parenthetically, it should be noted that the sanctions in question could only apply to criminals who committed theft professionally, making it a source of income ${ }^{28}$.

The death penalty (in collo punie, collo privare, collo persolvere, vita privari, caput amputare) could be ordinary, and then performed by beheading or hanging (suspensio), and qualified, when combined with particular torments (e.g. starvation, quartering, burning on stake, poisoning or burying alive), whereby the presented act did not set it in any provision. Beheading was considered to be the mildest and most graceful way to execute a sentence, so it was reserved for a privileged state, and the hanging was seen as disgraceful and was most

\footnotetext{
24 „Item cum aliquis fuerit inculpatus pro forticinio vel diffamatus, talis sex testes producere debet, et illi testes pro ipso iurare debebunt, ipse autem solus non iurabit. Tamen eosdem testes de triplici geneloya producere debet pro sua infamia; quo utique testes terre seniores acceptabunt". [IMT, vol. 1, No. 22, p. 31]; The indicated article was omitted in Bandki's edition, whereas in Helcel it was mentioned as IX [H, p. 272].

25 „Item. Gdi ktho o zlodzyeystwo bandze obvynyon albo osromoczon taky schesczyąn swyatkow wandze swoyan nywynnoscz ocziscz a ony swyatkowye za nim mayąn przissyancz a on sam nyema przissyangacz ale wschdi thi iste swyatky a troyga rodu o swoyąn sromothąn slawycz ma ktore wschdi starschi zemye prziymąn”. [Prawa, op. cit., p. 3; cf. J. Lelewel, Księgi, op. cit., p. 134].

26 „Item quando princeps aliquem hominem pro furticinio inculpaverit, ipsum asserens furem, extunc eidem terminus ad sex septimanas, iterum ad secundas [sex] septimanas et superflue ad tercias sex septimanas assignetur et si iterum in eisdem decem et octo septimanis iustum se non fecerit, tunc princeps in sua bona hereditaria et mobilia se intromittere debebit, ipse autem cum collo suo debet se vitare”. [IMT,vol. 1, No. 22, p. 31]; Bandki provides the followingheadline for the article Modus justificandi, quibus crimen furti a principe obiicitur and places it at position number 10 [IP, p. 419], whereas in Helcel it is given as XII [H, p. 272].

27 „Item. Gdi nyektere xanząn nyektorego czlowyeka o kradzecz o zlodzyeystwo obvyuilibi gdi zlodzyeyem myenyecz thedi yemu rok naprzod za schescz nyedzel a i daley na wthoran schescz nyedzyel a nadwischsche za trzeczyąn schescz nyedzyel ma bicz dan pakli w tey osmynaczcze nyedzel sprawyedlywi syąn wzruczicz a on s schiya ma syąu vyarowacz”. [Prawa, op. cit., p. 3; cf. J. Lelewel, Księgi, op. cit., p. 135].

28 The Masovian law also distinguished between individual cases of theft. For example, for stealing grass from a meadow there was a fine of six grivnas ( 7.5 groschen), paid both to the claimant and to an official appointed by the duke. [the Statute of 26 November 1397, art. 2: De furto ponderis graminum, IMT, vol 1, No. 48, p. 71].
} 
often used in convictions for theft ${ }^{29}$. However, the penalty of confiscation of property (bona perdere, bona confiscare) was regarded as a very severe sentence because it additionally included the family property. It affected the whole family of the perpetrator, which in practice meant crossing out the social position not only of the perpetrator but also of the relatives ${ }^{30}$. The property confiscation was most often pronounced as a punishment in addition to the death penalty, proscription or infamy.

At the same time, paragraph 12, De eodem ${ }^{31}$ (in the translation of Maciej of Różan mentioned at the position 13, bearing the heading Zlodzey gdi vesmye ot plathan wschitko zaplacz $y^{32}$ ), excluded the penalty of the confiscation of property, which was to be preserved in the majesty of law by his wife and children, in the case of a thief, who had already been beheaded. However, the indicated provision had to apply to persons who had been beheaded for the aforementioned crime before the announcement of the Act of 27 April 1377, since the preceding article was applied with reference to thieves not yet convicted of penalties.

The provisions concerning thievery ended with paragraph 13, Articulus ${ }^{33}$, which was indicated by Maciej of Różan as 14 and entitled Gdi zlodzyeya w czudzey zemy obyeschąn xanza wesmye yego gymyenye $e^{34}$. The provision in question introduced another difference with regard to the penalty of confiscation of property and normalised the legal and penal situation of the perpetrator, who after committing a crime in one land, fled to another, where he was finally hanged. In that situation, only the part of the family property which was due to him by law was subject to confiscation in favour of the Duke and the property belonging to his brothers was excluded from it.

The article no. 7 of the statute was a phenomenon in the scale of the whole Polish legislation. In Jakub Sawicki's book it bears the heading Actor homicidii queratur ${ }^{35}$, and

\footnotetext{
29 The first recorded case of execution of the sentence of death by hanging in Masovia was the case of Jan Czapla, a scholastic scholar from Płock and Włocławek, who was hanged in 1239 pursuant to the sentence of Duke Konrad I of Masovia. Due to the fact that after the execution of the sentence the body of the convict was not buried and was hanged vis a vis the Płock Cathedral, it should be considered a qualified type of hanging.

30 J. Bardach, B. Leśnodorski, M. Pietrzak, Historia, op. cit., p. 160.

31 „Item quando princeps aliquem furem suspendere mandaret, et aliquam super eo vindictam sumeret pro suis excessibus, tunc ad suam hereditatem vel ad sua bona ipse princeps minime intromittere se debebit, quia ipse omne debitum in collo suo persolvit, sed utique uxorem vel pueros ipsius in eisdem bonis residere debet permittere pacifice”. [IMT, vol. 1, No. 22, p. 32]; Bandki placed the indicated provision under number 11 entitled it as: Fur totum delictum collo exsolvit [IP, p. 419], whereas in Helcel it was given position 13 [H, pp. 272-273].

32 „Item. Gdi xanząn nyekterego zlodzyeya albo nyekteran zlodzyekąn obyesycz kazalbi a na tem pomstą vesma za gych grzech tegdi $w$ gich dzyedzini albo gymyenya to iste xanząn w wyanzowacz albo wrzuczacz syąn nyema bo wschitek grzech schiyąn swąn zaplaczyli a wschdi zona i dzyeczy gich w gymyenyu mayan bicz przepusczeny pokoynye”. [Prawa, op. cit., p. 3; cf. J. Lelewel, Ksieggi, op. cit., p. 135].

33 „Preterea, quando aliquis homo furticinium aliquod perpetraret, et postmodum fugeret in terram alienam, et ibidem in terra aliena suspenderetur, extunc dux in [et] ad omnia bona sua libere se intromittat, et ipsa bona perpetua obtineat". [IMT, vol. 1, No. 22, p. 32]; Bandki placed the indicated provision under number 12 entitled it as:Fur in exilio suspensus [IP, p. 419], whereas in Helcel it was paragraph 14 [H, p. 273].

34 ,Item. Gdi nyekteri czlowyek zlodzyeystwo nyektore popelnylbi a potem bi s zyemye uczyekl w zyemyąn gyuschan a tambi $w$ zjemy czvdzey obyeschon bil tegdi $w$ yego czanscz dzyedzini pan xanzan $w$ wyanzacz ma ale w czanscz braczyey yego nyema syan w matacz ale dobrowolnye bes wschego vgabanya braczya se yego czansczy swe possyandąn”. [Prawa, op. cit., p. 4; cf. J. Lelewel, Ksiegi, op. cit.,p. 135].

35 „Item si inter aliquos homines, cuiuscunque condicionis extiterint, gwarra seu dissensio evenerit, extunc, ille, cui pater, frater vel quispiam ex amicis est interfectus, reum temptare et inspicere debebit, iustum vero non debebit impedire. Et si ausu temerario iustum in domo vel extra domum irritaverit, tunc honore et bonis suis privetur et precipue ipsum cum collo evitare opportebit”. [IMT, vol. 1, No. 22, p. 30]; In Bandki, the indicated provision was
} 
in the translation of Maciej of Różan it is entitled $O$ manzoboysthwye $e^{36}$, and it constitutes the motto to the present text. The aforementioned provision was the first regulation under Masovian law concerning private wars, the so-called vendettas (guerrae, dissentiones,

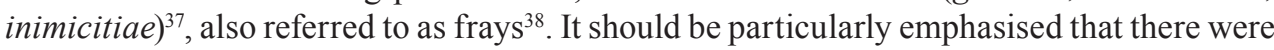
no provisions in the Crown that would regulate the conditions for revenge or limit it. The consequence of homicide (murder) of a noble man (knight) by a person also coming from a privileged state was the appearance of vendetta between the family of the deceased person and the family of the killer and entitled to bloody vengeance sanctioned by law, which covered all the killer's family members, even children as well as their subjects ${ }^{39}$.

However, the paragraph in question categorically prohibited vengeance against other members of the family, limiting the retaliation to the killer himself, under the threat of the loss of life, infamy, or the confiscation of all property, which illustrated the scale of the problem in terms of security and public order, seeing that the law provided for such a severe penalisation. The penalty of infamy (infamia, honorem perdere), similarly to proscription, entailed the deprivation of noble honour but, contrary to calling up, it was not associated with exile from the country because it was assumed that the person sentenced to infamy was to live in a state where his/her legal and social status was to be impaired ${ }^{40}$. For example, the infamous person was deprived of a legal capacity and, as a result, (s)he could not, inter alia, go to court, lease offices or be a party to private contracts.

In addition, the regulations strictly connected with the crime of homicide (homicidium) ${ }^{41}$ include the sections determining the amount of the were-gilt, which was a monetary private penalty and was a sum paid for the head of the person killed for the benefit of his family. Article 15, Homicidium militis super militem ${ }^{42}$ (in the translation of Różański entitled Gdi wlodika zabye wlodikąn and given as section $16^{43}$ ), determined the amount of were-gilt for

placed at the end and is entitled: Homicida quaeratur et justus dimittatur [IP, p. 420], whereas Helcel used the same sequence [H, p. 271].

36 „Item. Acz myedzy nyekthorimy ludzmy kthorego kolibi stadla bily valka albo zwada przygodzylabi syan thedi on koти oczyecz brath abo ktho s prziyaczol przes nyekogo bilbi zabith schvkacz crzywego i patrzacz ma ale sprawyedliwego nyema gabacz paklibi smyalosczyąn zlosczywąn prawego $w$ domu albo procza domu nagabal tedi ten czo nagaba czczy i gymyenya ma bycz zbawyon a ossobnye se schiyan parowacz syan musi". [Prawa, op. cit., p. 2; cf. J. Lelewel, Ksieggi, op. cit., p. 134].

37 „Item si inter aliquos homines, cuiuscunque condicionis extiterint, gwarra seu dissension evenerit...”. [Statut z 27 IV 1377 r., art. 7: Actor homicidii queratur, IMT, vol. 1, No. 22, p. 30].

38 „Acz myedzy nyekthorimy ludzmy kthorego kolibi stadla bily valka albo zwada...”. [O mąnzoboysthwye, Prawa książat mazowieckich..., p. 2].

39 J. Bardach, B. Leśnodorski, M. Pietrzak, Historia, op. cit., p. 157; To find more about the topic see, for example: R Hube, Wróżda, wróżba i pokora, in: Romuald Hube Pisma,vol. 1, Warszawa 1905, pp. 312-335.

40 J. Rafacz, Dawne polskie prawo karne. Częsć ogólna, Warszawa-Kraków-Lublin 1932, p. 163; To find more about the topic, see, for example: B. Łoziński, Infamia studyum prawno-społeczne, Lwów 1987.

41 The Masovian law, like the Crown Law, did not distinguish between the concepts of killing and murder. For this reason, all acts referred to as murder or killing in other legislation, in Masovia were referred to by means of one term, i.e. murder.

42 „Item quando miles militem interfecerit, pro milite interfecto quadraginta marcas grossorum monete communis numerique in terra Mazovie currentis persolvere tenebitur interficiens". [IMT, vol. 1, No. 22, p. 32]; Bandki provided the following headline to the indicated paragraph Homicidium militis per militem and placed it at position 14 [IP, p. 419], whereas it was omitted in the Helcel's edition.

${ }^{43}$ „Item. Gdi wlodika zabiye wlodikan za wladiką zabytego cztirdzyesczy grziwen zaplaczycz bandzye vynen”. [Prawa, op. cit., p. 4; cf. J. Lelewel, Księgi, op. cit., p. 135]. 
lower knighthood or Włodyka, at 40 grivnas, i.e. 20 kopas of groschen ${ }^{44}$. At the same time, it should be noted that the variety of the noble layer in legal terms and specifically, in the aspect of the were-gilt penalty, was specified for the first time in the statute of 20 March 1390, published by Duke Janusz I the Elder, where the were-gilt penalty amount as regards a nobleman was determined to be 48 kopas of groschen, whereas for a Włodyka, as before, it was set at 20 kopas groschen ${ }^{45}$.

In the translation of Maciej of Różan, unlike in the Latin editions, there is also a provision determining the amount of the were-gilt for killing a peasant ${ }^{46}$, bearing a heading Manzoboystwo kmyecza and submitted as an article $18^{47}$. Under the quoted paragraph, the killer had to pay the family of the killed person, i.e. his wife and children, 4 kopas of groschen and the same amount to the peasant or to the master of the peasant (heir).

Moreover, the Act of 1377 regulated the amount of punitive damages for beating or wounding a peasant by a nobleman (a knight) as well as laid down the principles for seeking justice by way of court proceedings and the amount of the so-called 'bite' (beat). According to Article 14, Quantitas pene pro verbere kmethonum ${ }^{48}$, in the Różański's translation mentioned as 15 and entitled Vyna gdi zyemyanym zbyye kmyeczya ${ }^{49}$, the beaten or wounded peasant was obliged to file a complaint with the court, called mourning, whereas his master had to assist him in court. In case of a win, the victim was to receive punitive damages in the amount of six skojecs. Punitive damages constituted a monetary private penalty and its amount was always a fraction of the were-gilt. At the same time, the convicted person had to pay a separate fine of three grivnas for the benefit of the master of the aggrieved peasant, the socalled 'bite' (poena percussionalis lub percussionis), and a public penalty for the benefit of the Duke, which was not specified in the quoted paragraph. However, it should be stressed that the amount of the Duke's penalties was usually equal to the compensation provided for by the law for the injured party, whereby it is not clear from the indicated provision whether the perpetrator was to pay the equivalent of the 'bite' or the punitive damages.

44 In the period in question, the grivna in Masovia, unlike in the Crown, was 30 groschen, so the płat was 20 kopas of groschen, which constituted 25 Polish grivnas. Towards the end of the 14th century, monetary benefits were defined in kopas of groschen (grossi), which soon eliminated grivnas from circulation..

45 ,[1: Quantitas homicidii nobilium] Quod quicumque nobilis interfectus fuerit, [occisor] quinquaginta sexagenas grossorum minus duabus sexagenis pro capite ipsius solvere teneatur. Cum vero miles quivis interfectus fuerit, qui non est nobilis, sed solum habet ius militare, pro eius capite 20 sexagene grossorum solvi debentur”. [IMT, vol. 1, No. 39, art. 1, p. 57].

46 In the duke statutes, the simple people appear under the name of peasants (kmethones), who seem to form a homogeneous and equal group in the face of the law.

47 „Item. Gdibi myedzi kmyeczmy manzoboystwo by syąn sstało albo przigodzylo, tegdi za kmyecza zabitego zenye albo i dzyeczyem taky manzoboycza cztirzy kopi a xandzu albo dzyedzyczowy druge cztirzi kopi zaplaczicz ma". [Prawa, op. cit., p. 4; cf. J. Lelewel, Księgi, op. cit., p. 135].

48 „Item quando aliquis miles kmethonem vulneraverit, tunc kmetho super eundem militem debet querulari, dominus vero eiusdem kmethonis circa iudicium assistere debet. Et si idem kmetho super adversario iudicialiter adquesierit, tunc talis dominus, cuius kmetho fuerit vulneratus, tres marcas recipiet; kmetho vero pro suis vulneribus sex scotos accipiet, penis ducalibus exceptis". [IMT, vol. 1, No. 22, p. 32]; In Bandki's edition, this provision is referred to as 13 and is entitled Poena pro verbere kmethonum [IP, p. 419], whereas in the Helcle's edition it was placed in position 15 [H, p. 273].

49 „Item. Gdi nyektori wlodica kmyecza zbiye albo rany tegdi kmyecz ma nayn zalewacz a pan tego kmyecza przed sandem staacz ma a gdi ten isti kmyecz na swem przeczywnyku zisczee sandownye tedi pan yegosch kmyecz bil ranyon albo zbith swego kmyeczya trzi grziwni vesmye a kmyecz za swe rani schescz skoth vesmye ale vini xanzancze ossobnye viyawschi”. [Prawa, op. cit., p. 4; cf. J. Lelewel, Księgi, op. cit., p. 135]. 
Broadly understood rapes (violentia) both on a person and property constituted a separate group of crimes whose common denominator was the use of physical coercion. The rape on a person included, in particular, the kidnapping or rape of a woman. In the translation of Maciej of Różan there was a section Gwalt kmyotownye (mentioned as 17) ${ }^{50}$, omitted in all Latin editions. Under the indicated provision, any use of violence against a woman or a widow, as well as rape of a virgin or a maiden, was punishable by four grivnas to compensate the victim and the same amount to the duke or to the duke's officials entitled to public prosecution. Concentrating on the headline of the present article it should be noted that it referred only and exclusively to simple folk victims which is also clearly indicated by the nature and the amount of the penalty provided for in it.

The provision bearing the headline in Jan Bandtki's translation De his, qui alios invadunt (given as the seventh) ${ }^{51}$ was omitted in the edition of Jakub Sawicki, whereas in Antoni Helcel's edition, it was placed as section $8^{52}$. The provision was also taken into account in the Różański's translation, who mentioned it as eighth and provided it with a title: $O$ them gdi kogo gaba gwalthem ${ }^{53}$. The abovementioned provision regulated the procedural situation when there were more perpetrators of violence against the victim than one (samotrzecz na czye albo samowthor ${ }^{54}$ ). If only one of the perpetrators was known to the victim, it was possible to lodge only a formal complaint against the perpetrator, leaving out the rest of the accomplices. Then, in order to prove his innocence, the defendant had to exonerate himself by the oath of witnesses, whereby their number was not specified. If the offender failed to fulfil his or her obligation, the offender was to be sentenced to as many sentences as there were accomplices and the victim could no longer lodge a complaint against the others.

A separate group of crimes investigated on the basis of a private complaint were crimes committed against noble honour, which included, in particular, slander (calumnies),

${ }^{50}$ „Item. Gdi ktho smyalosczyan zlac nyewyesczye albo wdowye gwalt vczinilbi albo dzewcze dzyeviczstwo albo panyenstwo zgwalczil, cztirzi grziwni za thaky gwalt dacz bandze vynen viyawschi vyni xanzancze sandzi albo ktorich kole gyanshich czestnykow". [Prawa, op. cit., p. 4; cf. J. Lelewel, Ksieggi, op. cit., p. 135].

${ }^{51}$ „Item si evenerit: quod super aliquem hominem inimieus, vel quispiam alius, eum complicibus suis mettertius, vel metdecimus, vel pluribus personie violente irruerit et invaserit, ipsum interficere volens, seu ei aliquid impedimentom inferre cupiens, si tunc ille, super quem invasio facta est, aliquem ex eis cognoverit, talem ad judicium citare debet pro hujusmodi violenta invasione, et ille, qui pro tali excessu inculpatur, debet suam innocentami cum plenis testibus expurgare, ita, quo cum illis nunquam super eum invasit, neque superequitavit, manu violenta, et animo malo interficiendi eum, aut aliquo impedimentom sibi inferendo. Et si innocentiam suam hoc modo expurgaverit, liber erit a citatione et inculpatione, si vero non expurgnaverit innocentiam suam, talis in toto et in poenis condemnabitur, in quo actio fuerit contra ipsum mota judicialiter. Et eo facto idem actor postea, quos serum in eadem invasione fore crediderit, non debebit pro eodem facto impedire". [IP, p. 418].

52 „Item, si contigerit, quod super aliquem hominem inimicus vel quispiam mettertius vel secundus irruerit, ipsum vulnerare vel interficere volens, seu aliquod nocumentum et inferre, et si tunc [ille], super quem venerant, unum ex eis cognoscere valuerit, illum ad judicium citare debet, et ille, qui est pro tali excessu inculpates, debet suam innocentiam cum testibus expurgare et exbrigare, ita, quod cum eisdem, qui super eum venerant, in communitate non fuisset equitatus". [H, p. 271].

53 „Item. Acz bi syąn przigodzilo zebi nyektori nyeprzyiaczel albo kthokolibancz samotrzecz na czye albo samowthor na nyekogo wrzvczil syąn gy zabycz chczancz albo yemu nyektore gabanye vczinycz zandayancz pakli on na kogo przischly yenego s nich posnacz może takiego do sandu poswacz ma a tey ktorisch o thaky grzech obvynyon ma svoyan nyevinnoscz se swyathky oczisczycz tako ze s nymy naan nyeyesdzyl a gdi nyevinnoscz oczisczy praw bandzye paklibi nyeoczisczyl tedy $w$ tako vyele vin potaupyon bandzye w yako vyelu zaloba naan bila a potem ten isti isczyecz drugich ktorich syąn domnyma ze s nym bily o than rzeecz nyema gabaacz". [Prawa, op. cit., p. 2-3; cf. J. Lelewel, Księgi, op. cit., p. 134].

54 Ibid. 
defamation and abuse. The offences raised were punishable only if the injured party was a person from a privileged state. All the indicated dishonorable acts were treated as allegations of inferiority, which in the discussed period in Masovia was called a rebuke of nobility ${ }^{55}$. The act aimed at blotting out the stain was called purification. The Duke's Statute of 27 April 1377 ended with the section 17, Quantitas vituperii militis per militem ${ }^{56}$ (translated by Maciej of Różan and also mentioned on the last position, i.e. number 20, and entitled Vyna prziganna gdi wlodica przigany wlodicze $e^{57}$ ), regulating the above issues.

The insulted person, who filed a complaint with the court, had to prove his nobility by oath of witnesses, two from each of the families, in total six. Providing the above evidence was tantamount to purification. At the same time, the indicated provision provided for a penalty for the wrongful nobility reproval, which amounted to 5 grivnas, due to both the victim and the duke. The condition for inflicting the indicated penalty was the victim's exoneration upon the rebuke of nobility during the court proceedings.

The regulations in the field of criminal law, included in the Statute of Sochaczew of 27 April 1377 occupy an exposed place against the background of other legal regulations. 12 sections, in total, were devoted to criminal law, taking into account both the Latin text and the translation into Old Polish made by Maciej of Różan, which accounts for more than half of all provisions. The majority of articles referred to substantive criminal law, while the subject matter of the trial was outlined only in general because it concerned almost exclusively the rules of providing evidence by the oath of witnesses. Much attention was paid to thievery and broadly understood rape, which probably found its justification in everyday problems of the subject of the Masovian Piast Dynasty. It should be at the same time noticed that the rulers of Masovia cared for all the subjects because the statute contained norms concerning the privileged state and the simple people. From that time on, every inhabitant of the Masovia region could invoke a specific regulation entitling him to seek justice. However, the regulation concerning vendetta, included in paragraph 7, deserves outstanding praise because there is no provision regarding thereof in the Crown Law.

The first Masovian statute is distinguished by the diligence of edition and a wide range of issues dealt with. The subsequent statutes of Dukes generally covered only the selected problems limited as regards the topics. The aforementioned act commenced a vigorous legislative activity of the rulers of Masovia, who, starting from 1377, published numerous

\footnotetext{
55 W. Semkowicz, Nagana i oczyszczenie szlachectwa w Polsce XIV. i XV. wieku, Lwów 1899, p. 6.

56 „Item quando aliquis miles alicui militi vituperium intulerit, extunc ille, cui vituperium est illatum, suam miliciam approbando, debet statuere ex sua geneloya duos pociores et seniores, de duobus geneloys aliis per duos testes producere debet in testimonium, et cum approbaverit, extunc ille diffamans diffamato quinque marcas pro vituperio et V duci dare debebit”. [IMT,vol. 1, No. 22, p. 33]; At Bandki's, this provision is placed as the penultimate, i.e. 16, and bears the heading Quantitas vituperii militis per militem [IP, p. 420], and in the Helcel's edition it was mentioned as the last one, i.e. 18 [H, p. 274].

57 „Item. Gdi kto komu przigany tho yest wlodica wlodicze tegdi on komu prziganyono swoje wlodziczstwo ma dowyescz stawyąncz s wlostnego rodu dwu lepschu i starschu a se dwu rodu dwu lepschu tho yest s kazdego rodu dwu powyescz ma na swyadeczstwo a gdisch doswyatczi tegdi on ktori prziganil pyancz grziwen onemu komu prziganil a pyąncz grziwen xandzu dacz ma”. [Prawa, op. cit., p. 4; cf. J. Lelewel, Księgi, op. cit., p. 136].
} 
statutes $^{58}$, and also edicts ${ }^{59}$, decrees ${ }^{60}$, mandates $^{61}$ and ordinances ${ }^{62}$. The above provides entitlement to draw a conclusion that in the last two centuries of its sovereignty, Masovia distanced itself from the Crown in the pursuit of order and unification of the domestic legal system.

\section{The regulations in the field of criminal law in the Statute of Sochaczew (27 April 1377) Summary}

This article is the first comprehensive overview of the criminal regulations of the first Statute of Mazovia, which was announced by Prince Siemowit III of Masovia on April 27, 1377 in Sochaczew. The authoress examines 11 criminal laws, which cover more than half of the act. The article presents the legal and penal regulations concerning: the conditions of taking revenge, villainy (robbery and persistent thievery), broadly defined rape on a person, the amount of were-gild for murdering a Włodyka (a representative of lower knighthood) and a well-to-do peasant, complicity, the defamation of people of high rank (i. e. the rebuke of nobility), the requirements on which one can exonerate themselves in court, as well as the amount of compensatory damages for beating or wounding a well-to-do peasant. While discussing specific legal articles, the author explains the basic notions concerning mazovian criminal law both substantive and procedural, in particular: the penalty of proscription, a vendetta, the penalty of infamy, the rebuke of nobility, exoneration, were-gild and punitive damages. At the same time, the article presents the issue of the death penalty and confiscation of one's property, which were the most severe penalties for convicted criminals. The article concludes with the summary of the conducted research.

Keywords: masovian law, criminal law, Sochaczew statute, manslaughter, villainy

About the author: Patrycja Ewa Herod, PhD, is a graduate of the Faculty of Law and Administration of the University of Warsaw (2008) and a graduate of the Cardinal Stefan Wyszyński University in Warsaw (2011), where she defended with distinction her doctoral thesis entitled "The development of the Masovian law against the background of political and structural transformations in Masovia until the fifteenth century under the guidance of Prof. Jolanta M. Marszalska (2014). In addition, she is an advocate in the Bar Association in Warsaw (since 2013). The main subject of her research interests is the history of the Middle Ages, with particular emphasis on the history of law and the Masovian land. She is the author of several articles, mainly devoted to the medieval history of Masovia, and has prepared more than 40 subject matter entries, which appeared in the Catholic Encyclopedia.

\footnotetext{
5846 statutes have survived till present times, with nearly 262 articles, but it should be stressed that their number depends on a given edition, from which the individual sections were counted, so one can count and find many more.

59 See: e.g. IMT, vol. 2, No. 220, 222.

60 See: e.g. IMT, vol. 2, No. 251.

61 See: e.g. IMT, vol. 2, No. 203-204, 210, 219, 227, 240-241, 245, 253, 257.

62 See: e.g. IMT, vol. 2, No. 193.
} 